NBER WORKING PAPER SERIES

\title{
THE INTERNATIONALIZATION OF \\ EQUITY MARKETS
}

Jeffrey A. Frankel

Working Paper No. 4590

\section{NATIONAL BUREAU OF ECONOMIC RESEARCH 1050 Massachusetts Avenue Cambridge, MA 02138 \\ December, 1993}

This introduction was written for a National Bureau of Economic Research conference, held at the Pan Pacific Hotel, San Francisco, California, October 1-2, 1993. The volume, The Internationalization of Equity Markets, is forthcoming from the University of Chicago Press, Chicago. The author would like to thank Stijn Claessens, Charles Engel, Wayne Ferson, Gikas Hardouvelis, Campbell Harvey, and other conference participants for comments on the introduction. This paper is part of NBER's research program in International Finance and Macroeconomics. Any opinions expressed are those of the author and not those of the National Bureau of Economic Research. 
NBER Working Paper \#4590

December 1993

\title{
THE INTERNATIONALIZATION OF
} EQUITY MARKETS

\begin{abstract}
ABSTRAC'T
This introduction to a forthcoming NBER volume on "The Internationalization of Equity Markets" argues that the existing finance literature has in some respects not kept pace with world trends. Most empirical studies fail to take due account of the diversity of assets offered by countries around the world, the diversity of locales in which investors live, and the diversity of institutional peculiarities that characterize the markets in which assets and investors are brought together. Four of the papers in the volume are econometric studies of asset pricing and homecountry bias in intemationally integrated equity markets. The other four examine such issues as emerging markets, country funds, trading volume, location, taxes, controls, and other imperfections in intemational markets.
\end{abstract}

Jeffrey A. Frankel

Deparment of Economics

787 Evans Hall

University of California

Berkeley, CA 94720

and NBER 
THE INTERNATIONALIZATION OF EQUITY MARKETS: INTRODUCTION

The internationalization of equity markets encompasses the intersection of three important trends. The first trend is relevant even to the United States, where, as in the United Kingdom, equity markets have long been a dominant part of the financial system. Here the trend is increasing integration with the rest of the world, as American investors look abroad, foreign investors buy U.S. equities, and prices on the New York Stock Exchange become increasingly linked with those in London, Tokyo and around the world. By 1993, for example, American holdings of foreign stocks had reached $\$ 210$ billion, more than double the level of 1990 .

The second trend is particularly relevant to countries such as Japan, Germany and France, where equity markets have not in the past been as developed or active. It is securitization, defined as increased reliance of the financial system on markets in equities and bonds at the expense of banks and other financial intermediaries. By 1989, the capitalization of the stock market in Japan, for example, had surpassed that of the U.S. market.' World stock market capitalization for developed countries exceeded ten trillion dollars in 1991, quadruple the nominal level of ten years earlier.

The third trend is particularly relevant to newly industrializing countries, though it, like the first two trends, can aiso be identified with other sorts of countries. It is the opening of national financial systems to international financial flows and institutions, as governments remove capital controls and other barriers. Foreign purchases of equities from developing countries were estimated at $\$ 9.6$ billion in 1992 . While this is still small compared to the 
volume of gross flows among industrialized countries, it is almost three times the level of 1989, and is bound to play an increasingly important role in the financial development of the recipient countries in the future. ${ }^{2}$

An increasingly integrated, securitized and open world financial system suggests important questions, and offers a rich set of data with which to attempt to answer them. Some of these questions are new ones raised by the international environment itself. What are the gains to intemational diversification, for example, from the viewpoint of a U.S. investor? To what extent are markets in fact now integrated across countries? Do investors still exhibit an unexplained home-country bias, despite the degree of globalization that has taken place? What is the role of the specific times and locations around the world at which stocks are traded?

Other questions are versions of questions of longstanding interest in the context of domestic equity markets. Are the markets efficient? Are expected retums determined in world markets by variances, covariances, and the price of risk as suggested by the Capital Asset Pricing Model (CAPM)? If not, what is the correct alternative model? To answer these questions, we will also have to ask what is the appropriate international version of CAPM, or of other models of asset-pricing that have been developed in the domestic context?

Most less-developed countries have previously been "financially repressed" and partially closed off from world financial markets. What are the effects when such countries liberalize and open up to foreign investors? Do the theoretical gains from trade across time 
and across states of nature in fact show up in the data? How can one disentangle the extent to which fundamental shocks in such economies are independent of those in industrialized economies (offering a valuable opportunity for diversification) and the extent to which barriers continue to segment the markets? Have country funds offered an effective first wedge into markets where barriers still prevent foreign investors from entering freely?

These are some of the questions which this conference seeks to address. Many of them have until recently been underexplored, sufficiently so that it is possible to make relatively tangible progress.

\section{PART I: ASSET PRICING AND HOME COUNTRY BIAS IN INTERNATIONALLY INTEGRATED MARKETS}

\section{Limitations of the Existing Literature}

Models of equity-pricing have been the centerpiece of the finance field over the last 25 years. The literature has continued to develop rapidly in a technical sense. Such innovations as allowing variation over time in first and second moments of returns (i.e., in expected rates of return, variances, and covariances), are very important if one hopes to be able to capture a world of changing realities. In other respects, however, the research has not entirely kept pace with some of the major phenomena in world markets that need to be addressed.

Two shortcomings of standard tests of asset-pricing models have been known for a 
long time, but have become even more important as equity markets have become internationalized. More than fifteen years ago, Richard Roll (1977) emphasized the importance in tests of CAPM of using as comprehensive a set of assets as possible. Today, a majority of tests conducted by American researchers leave out other countries' assets entirely. Other tests conducted by international financial economists often commit the symmetric sin of concentrating on a sample of countries' bonds, either omitting equities entirely or else simply adding a single equity index like the Standard and Poor's 500 to the list of assets. Both approaches blithely omit categories of assets that are some of the most important in world markets.

A second shortcoming of the standard tests is that they usually measure all returns in terms of dollars. The implicit assumption is that any asset whose return is fixed in terms of dollars, such as U.S. deposits, is completely safe, and that the risk of other assets can be measured by their correlation with the market basket return expressed in dollars. If U.S. investors were the only ones whose behavior mattered, this assumption would not be too bad at short horizons. Because monthly variability in the U.S. consumer price index is so low -. compared to the variability in the prices of stocks, bonds, and foreign exchange -- the real value of dollar deposits is almost certain at a horizon of one month or less, from the viewpoint of American investors.

U.S. investors, however, are not the only ones in the market, either the market for U.S. stocks or the market for foreign stocks. Just as American investors find dollar assets less risky than deutschemark or yen assets, so do Japanese investors find yen assets less risky and German residents find mark assets less risky. If major stock markets are integrated, then 
the behavior of each nationality of investors who participate in this integrated global market is relevant. More precisely, in market equilibrium, each investor nationality should be weighted by the size of its total portfolio. The weight has been shifting away from U.S. investors. Because U.S. assets abroad are now exceeded by foreigners' assets in the United States, it would be more correct to oversimplify by assuming that the representative global investor in world markets is a foreign resident, than to continue with the old oversimplification of assuming that the representative investor is an American.

If purchasing power parity (PPP) held among currencies, the proper test would be a simple matter of identifying the price index of the appropriate international basket of goods consumed by investors, and measuring asset returns in terms of it. ${ }^{3}$ PPP does not hold in the short run, however, not even approximately. Thus, using a single composite international price index is not much better than using a dollar price index. There is little way around letting investors of different countries behave differently. We will use the phrase "preferred local habitat" to refer to the implication that follows from this failure of PPP, the proposition that investors who live in different countries will use different reference currencies to evaluate what is a safe asset and what is a risky asset.

More than fifteen years after these points were first emphasized, ${ }^{4}$ very few modem tests of international asset pricing seriously address them. This refusal by most researchers to allow investors to live in whatever country they choose seems rather intolerant.

Other kinds of heterogeneity of investors across countries are possible as well. One can allow investors to have different degrees of risk-aversion, as in Engel's contribution to this volume, or to have different expectations regarding stock market performance, as in 
French and Poterba (1991). These extensions are probably lower-priority, however, than allowing for differences in the consumption basket.

The state-of-the-art work of Campbell Harvey (1989, 1991, 1993), alone and together with Wayne Ferson (1993, 1994), addresses some serious shortcomings of the previous literature. It allows expected returns to vary over time, by conditioning them on a set of observable instrumental variables, such as dividend yields. It also allows variances to vary over time, for example by means of the famous ARCH process, introduced by Robert Engle, and developed in subsequent elaborations, such as Bollerslev, Engle and Wooldridge (1988). In the technique of Harvey (1991), variances and covariances are also allowed to vary in a general way [somewhat analogously to the way first moments are allowed to vary in a completely unrestricted way in the method used by Charles Engel].

Many researchers have sought refuge from the mundane realities of CAPM tests -such as the aforementioned difficulty of measuring all assets -- by assuming a world of representative agents, each of whom maximizes an (identical) intertemporal expected utility function. The solution is more apparent than real, however, as the theoretical constructs in such models are often even more difficult to measure empirically. Moreover, a representative agent model is clearly inappropriate for addressing our second concern, heterogeneity of investors across countries. Dumas (1993) has considered the prospects for reconciling this model, which he calls the "orthodox General Equilibrium approach", with some of the stylized facts of international finance that concern us in this volume: PPP deviations, home bias in equity preferences, and differences in expected returns across 
countries. He concludes that CAPM, which he calls the "heterodox partial-equilibrium approach", is more likely to accommodate these stylized facts.

\section{International Factors and Rates of Return}

In recent work, Dumas and Solnik (1993) use instrumental variables similar to Harvey's to condition expected retums, but at the same time seek to move beyond the assumption that all investors live in the United States, to address the issue of preferred local habitats. Their technique for choosing between the intemational and classical versions of CAPM allows the data to suggest whether the retum on a country's equities is determined by putting weight on correlations with individual currencies, or solely by the correlation with the aggregate market portfolio. In Chapter 2 of this volume, Dumas extends this approach in the direction of addressing what I will call the Summers ketchup critique.

Larry Summers (1985) registered a complaint with research in finance: that it spends all its energies testing, essentially, whether the price of one-quart ketchup bottles bears the hypothesized relationship to the price of one-pint ketchup bottles. Summers was referring to the habit of testing the relationship between the first moment of stock retums and the second moment of stock returns, with no other data beyond stock prices entering the analysis. [One might add that the practice of using lagged stock retums as instrumental variables does little to reduce the circularity.] In a study of the ketchup market, one would hope to explain the price of ketchup in terms of such factors as wages, the price of tomatoes, the income of 
consumers, the price of hamburgers, the price of mustard, etc. Similarly, argues Summers, one would hope to be able to explain stock returns in terms of fundamental economic variables.

The Dumas study appearing here dispenses with the variables internal to the financial markets, such as dividend/price ratios, that others have relied on to predict returns. Instead, indicators of real economic activity are used as instrumental variables: for example, housing start authorizations, increases in manufacturing inventories, and the percent of companies reporting slower deliveries, and other variables found by Stock and Watson (1992) to be important in predicting real activity. Viewed in the light of the Summers ketchup critique of the circularity of the standard approach, the Dumas study is a commendable attempt to relate international equity returns to real economic variables. This line of inquiry is useful even if the real economic variables do not predict returns as well as do the financial variables, although one is reassured to see that these instruments have at least some statistical power. Dumas then tests the international conditional CAPM against the classic conditional CAPM and statistically does not reject the former. He also tests the classic conditional CAPM (against an unspecified alternative), and does reject it; so the reader's prior beliefs regarding CAPM will affect the way he or she wishes to interpret the findings.

Chapter 3 in this volume provides Ferson and Harvey's latest contribution to tests of international asset-pricing. They seek to bridge the gap between state-of-the-art finance and practitioners who engage in "asset-allocation" based on whatever observable variables seem to be useful for picking stocks. 
Like Adler and Dumas (1983) and Dumas and Solnik (1992), they assume that returns on individual assets will be related not only to the retum on a world market portfolio (the Morgan Stanley Capital International index), ${ }^{\mathrm{s}}$ but also to the return on holding a portfolio of G10 currencies. Ferson and Harvey interpret the two coefficients as betas, one on the world stock market portfolio and one on the currency portfolio, and let them vary over time as functions of certain attributes of the national equity markets. The idea is that attributes of the national markets should predict the cross section of future returns only to the extent that differences in the attributes across countries measure differences in the betas. Ferson and Harvey model the betas as functions of three groups of attributes: (1) valuation ratios, such as price-to-book value and price-to-cash-flow, (2) industrial structure, and (3) economic performance measures, such as relative GNP growth and relative inflation.

They test whether these betas are statistically related to expected returns on the assets in question, against a number of ad hoc alternative hypotheses. They do not, however, focus explicitly on second moments to test whether a higher level of risk on an asset requires a higher expected return to induce investors willingly to hold that asset -- as in classic tests of CAPM. The proposition that predictable components of returns must be risk premia is assumed rather than tested. This approach has become the norm in models of risk. ${ }^{7}$ As Bruce Lehman notes, yesterday's "anomalies" of predictability became today's risk premiums. [Possible alternative interpretations of predictability are considered below, in Part II.]

There is always a concern that a test of CAPM is not meaningful because one cannot actually measure the correct benchmark portfolio. The concern has given rise to a tradition 
of adding in whatever additional factors the researcher thinks might be useful in explaining returns. Ferson and Harvey $(1993,1994)$ have found oil prices, OECD industrial production, and OECD inflation rates useful in past work, but do not get very far with them here. The coefficients in cross-sectional regressions of returns on lagged attributes, which should be the factor premia if the attributes measure betas, are only weakly related to premiums for these global risk factors. Ferson and Harvey's tests do suggest that the attributes may be useful for modelling the world equity market and the currency portfolio. Findings that returns on some countries' stocks are related to observable economic factors will always be of interest to practitioners.

\section{Tests of the International CAPM and Home Country Bias}

The contributions to this conference by Engel and by Tesar and Werner test the international CAPM with a technique that addresses many of the limitations of the existing literature. ${ }^{8} \quad$ Like the state-of-the-art finance tests, Engel's test in Chapter 4 allows conditional expected returns to vary over time. Unlike these tests, however, the "CASE method" [Constrained Asset Share Estimation] does not require that the information set on which investors condition their expectations be limited to a handful of variables observed by the econometrician. Rather, investors' expectations, regardless on what they are based, can be inferred from their observed asset holdings. Asset stock measures do not have to be introduced extraneously; they are already implicitly present in the standard CAPM measure 
of the return on the overall market portfolio that everyone uses, as the weights that are used to aggregate individual assets' returns.

The downside of the technique, as Engel admits, is that the second moments must be modeled in an ad hoc way reminiscent of how other studies model the first moments. Variances and covariances must be assumed either to follow some sort of ARCH or GARCH process or to be related to lagged values of observable economic variables, if they are not assumed constant altogether.' Of course the same is true of other tests.

A second advantage of the CASE method is that the null hypothesis of international conditional CAPM is tested against interesting explicit alternative hypotheses. Most notably, it affords a natural test of CAPM against the Tobin model in which investors balance their portfolios across assets as general functions of expected returns, without necessarily diversifying optimally. One must conclude that this particular alternative hypothesis is of more interest to economists than to finance specialists, however, given the gulf that appears between the two strands in the literature. Other alternative hypotheses that one could imagine, and that are considered by other contributors to the volume, include market segmentation, noise trading, and the possbility that ex ante returns cannot in finite samples reliably be inferred from ex post realizations.

A third important advantage is that Engel allows his investors to live in whatever country they choose, like Dumas-Solnik (1993) but unlike most tests. In other words, residents of each country are allowed to have their own asset preferences, and their asset demands are then added up to arrive at the overall market equilibrium. This trick is accomplished by using cumulated data on countries' current account positions, measuring 
their net investment positions vis-a-vis each other. For example Japan's wealth increases at the expense of America's, when the former runs a current account surplus and the latter a current account deficit.

One of the nested hypotheses tested by Engel, his Model 3, seeks to dispense with the data on national wealths by assuming them constant and allowing their levels to be estimated endogenously. His Model 3 is in fact somewhat like the famous equation 14 of Adler and Dumas (1983), as tested for example by Dumas and Solnik (1992) or reproduced here as equation 1.1 in Dumas' chapter. (The main difference is that Dumas estimates betas in the traditional first step of a two-step method, while Engel imposes the CASE constraint in a single estimation procedure. This is a constraint of proportionality between the coefficients in the expected return equation, on the one hand, and the variance-covariance matrix of the error term in the same equation, on the other hand.) Engel finds that his Model 3 performs the worst of all the models he tests. Evidently it is necessary to allow for the fact that countries' shares of world wealth do in fact change over time.

Engel's results offer some relatively clear verdicts on some hypotheses that have been widely pondered. First, he does not reject the hypothesis that the coefficient of riskaversion is equal across countries (Model 2 in section IV of the chapter). The estimated coefficient of relative risk aversion is approximately 4.0. Second, the special case of ARCH is rejected against the more general GARCH.

Especially noteworthy are the verdicts on some of the hypotheses that are central to the goals of this conference. There is weak evidence (i.e., at approximately the ten percent significance level; see Section V of the chapter) that the international CAPM has some ability 
to predict expected returns. ${ }^{10}$ Investor heterogeneity appears to be key to the relative success of several versions of the model." Ultimately, however, Engel again rejects the CAPM, because the heterogeneity observed in the data is not quite of the right sort.

Previous results have sounded negative for the international CAPM, but they have been on less firm ground than Engel's. A failure to reject the hypothesis that expected returns are equalized internationally, within the CAPM framework, sounds like bad news for the model; but a failure to reject does not allow one to claim a positive finding. A rejection of CAPM against the more general Tobin altemative also sounds like bad news, but again is somewhat less compelling if the Tobin alternative itself has no explanatory power for expected retums. By paying due attention to a full intemational array of assets and countries of residence, Engel has been able to reject the constraints of the international CAPM in favor of a more general alternative that has a particular claim on our interest. That altemative, the portfolio balance model with an allowance for preferred local habitats, has a particular claim on our interest because it seems to be the only model that has predictive power for asset retums empirically, and at the same time follows from a widely-used theory. ${ }^{12}$

Tesar and Werner in Chapter 5 have a more direct way of addressing the failure of the standard tests of CAPM to allow diversity of investor residence. They work with data on purchases of assets from the balance of payments capital accounts of major countries. Previous researchers have virtually ignored these data. Large measurement errors in the balance of payments data are part of the explanation. Nevertheless there is much to be learned from the data, even with its imperfections, and the authors are to be commended for 
undertaking this line of research. A good example of the issues that are difficult to analyze without the balance of payments data is precisely the hypothesis of optimal diversification by investors of differing nationalities.

After exploring various patterns in the data, Tesar and Werner use the same technique as Engel to test CAPM. Instead of aggregating across investors in different countries of residence, however, they make use of their balance of payments data to examine the behavior of individual nationalities. In the last section of this paper, they concentrate on the asset demands of U.S. investors, due to greater data availability than for other countries. Their test is necessarily only a test of meanvariance efficiency of the portfolios held by American residents, rather than a test of the international CAPM hypothesis; but since the latter hypothesis amounts to the proposition that all important investors in the marketplace hold portfolios characterized by mean-variance efficiency, a test of Americans' behavior is certainly a useful piece of information. Like Engel, they are able to reject conditional mean-variance efficiency, against the more general Tobin alternative.

A major motivation for the volume, and especially for Tesar and Werner, is a puzzle that seems likely also to be connected with the statistical rejection of the international CAPM. Investors who reside in different countries are thought to exhibit a bias toward holding home assets. French and Poterba (1991), Golub (1991), and Tesar and Werner (1993) find that there is such a bias in portfolios actually held, notwithstanding the widely noted progress already made in recent years toward the globalization of equity markets. (The data used by Tesar and Werner (1993) for this purpose are the same sort that they use 
in their contribution to the present volume.) In 1989, U.S. investors reportedly held 94 per cent of their stock-market wealth in domestic stocks, Japanese investors held 98 per cent, and U.K. investors held 82 per cent. In 1990, pension funds in G-7 countries continued to hold more than 90 per cent of their assets domestically..$^{13}$ Why do they not each hold more of each others' equities? ${ }^{14}$

One can readily explain a substantial home-country bias in investors' holdings of short-term bonds, as opposed to equities. The explanation is rational preferences for local currency habitats. Assume a simple model of investors' portfolio allocations based on oneperiod mean-variance optimization (which is the CAPM). Assume further that goods prices are predetermined in the currency of the country where the good is produced, over a horizon as long as the maturity of the bond. Calculating the optimal portfolio for a given investor, even approximately, is very difficult because of sensitivity to expected rates of retum, which are difficult to measure precisely. Calculating the difference between optimal portfolios held by domestic and foreign residents is much easier, however, assuming that both share the same expectations (and, for simplicity, the same coefficient of risk-aversion, as in Engel's results). The reason is that the expectations component of the optimal portfolio share drops out of the difference.

Let $x_{A}$ be the share of their portfolio that Americans allocate to U.S. assets and $x_{G}$ the share of their portfolios that Germans allocate to U.S. assets. Then it can be shown that $x_{A}-x_{G}=\left[a_{A}-a_{C}\right][1-I / \rho]$, where $a_{A}$ and $a_{G}$ are the shares of their consumption that optimally-diversified American and German residents, respectively, allocate to U.S. goods, and $\rho$ is the coefficient of relative 
risk-aversion. ${ }^{15}$ Intuitively, to the extent that investors are relatively risk-averse $(\rho>1)$, they differ in their portfolio preferences in simple proportion to how they differ in their consumption preferences. The term representing the home-country bias in consumption, $a_{A}$ $a_{G}$, is certainly large in practice. Assume for simplicity that it takes its maximum value of 1 $0=1$. Let us try a value for the coefficient of risk-aversion that emerges from Engel's estimates: 4 . It follows that the measure of home country bias is relatively large: $x_{A}-x_{G}=$ .75. If residents of each country in fact hold a mere 10 or 15 per cent of their portfolios in foreign bonds $(.85-.15=.70<.75)$, that is fully consistent with optimal diversification! At first glance, home country bias poses no puzzle.

The puzzle arises in a portfolio that includes equities. To a first approximation, the retum on equities is determined as a random draw in the currency of the home country (i.e., in practice this retum has a surprisingly low correlation with the exchange rate). There is a substantial correlation of equity returns across countries; Ito and Lin's contribution to this conference constitutes the latest piece of evidence on how stock market movements are transmitted from one country to another. The correlation is far from 1, however, which is of course the reason why international equity investment offers a valuable opportunity to diversify.

The key point is that exchange rate risk is not an impediment to holding foreign equities in the way that it is an impediment to holding foreign bonds. Once investors have given vent to the home-country bias that optimally follows from differences in consumption patterns, in the form of bond portfolios that are relatively undiversified, there is little reason for their equity portfolios to exhibit the same home-country bias. Rather, in theory, 
American investors should take advantage of the opportunity to diversify by holding approximately the same amount of German equities as German residents hold. They can easily eliminate the gratuitous exchange risk by reducing their holdings of German bonds correspondingly or, equivalently, by selling marks on the forward market. (The prescription to hold foreign equities but hedge the exchange risk has been offered to portfolio-managers as a "free lunch." ${ }^{16}$ )

Clearly, investors' equity portfolios are in fact less diversified than this. In a framework that allows investors of each country to diversify among countries' stocks and bonds as they will, rejection of the CAPM constraint might be attributed to its implication that investors should exhibit home-country bias only in their bonds, not in their stocks. ${ }^{17}$ Tesar and Werner, certainly, infer that there is a significant home country bias puzzle -which cannot be explained by transactions costs -- from their evidence that investors trade a lot on the small fraction of the portfolio that they dedicate to foreign assets. They find that gross transactions volumes are very large compared to the magnitude of the corresponding net transactions volume. 


\section{PART II: EMERGING MARKETS, TRADING VOLUME, LOCATION, TAXES, CONTROLS, AND OTHER MPERFECTIONS}

We have seen that the tests, even those that make full allowance for the range of international assets to be held and the range of countries where investors live, seem consistently to reject the international CAPM hypothesis. Why? One possibility is that investors are sophisticated and markets are efficient, but CAPM does not hold because the assumptions on which the simple one-period mean-variance framework depends are not justified. The alternative possibility is that international equity markets fall short, in one way or another, of the ideal of a perfectly-integrated efficient market where rationally expected returns correctly price risk and investors are able to optimize fully. There are (at least) three ways that markets could fall short of the ideal, all involving an extra degree of heterogeneity arising from such factors as imperfect information. Investor heterogeneity must always be with us; otherwise it would be difficult to explain the high volume of transactions in the equities markets. But it arises more forcefully in a global context than in the domestic context. I have in mind an extra degree of heterogeneity beyond the mere fact of different national consumption baskets considered above.

First, integration may still be far from perfect, due to remaining taxes, regulations, legal differences, and imperfect transmittal of information across countries, segmenting some countries' markets from the world market. Such barriers may be the explanation for observed home-country bias. Second, because markets are not perfectly liquid, there may be a relevant dichotomy between "liquidity traders" and "informed traders". Third, in a world 
of imperfect information, some investors may make worse use of the available information than others. So-called "noise traders" may undergo waves of optimism or pessimism regarding investments in particular countries. Each of these three possibilities would be a departure from the Efficient Markets Hypothesis. They each play a role in the second half of the volume.

\section{Segmentation and Emerging Markets}

Imperfect integration, as a deviation from the Efficient Markets Hypothesis, is a possibility even in the case of industrialized countries. ${ }^{18}$ Japan, for example, had heavy restrictions on foreign stock ownership as recently as 1979 , and legal and information differences may still be disinducements to cross-border investment.

Imperfect integration is most evident, however, in the case of less developed countries. Many LDCs have undergone financial liberalization in recent years, spurring a boom in emerging markets. As these countries remove explicit barriers to cross-border investment, they incidentally provide us with convenient experimental data on which to try out tests of segmentation vs. integration. This underexplored area promises much exciting research. ${ }^{19}$

Studies of the extent of segmentation have been challenged by the difficulty of disentangling the implications of barriers to integration from the implications of independent economic shocks across countries. While the extent of independence of shocks provides an 
important incentive for cross-border investments and the extent of barriers provides an important obstacle, both can show up empirically in the same way: as a relatively low correlation between emerging markets and markets in industrialized countries. One approach is to divide countries into sub-samples, according to whether their markets are known to be open. Usually, however, liberalization is more of a gradual continuous process, rather than A one-time complete event.

Claessens and Rhee, in Chapter 6, study the process of opening by less developed countries, by making use of some interesting new indexes on the degree of foreign "investability," computed by the International Finance Corporation (IFC). They build on a standard test of segmentation in which returns on a countries' equities could either obey CAPM vis-a-vis the world market portfolio (if the markets are integrated) or vis-a-vis the domestic portfolio alone (if markets are segmented). They reject the hypothesis of complete integration for 10 out of 16 countries. For most of the countries they are not able to reject the opposite polar case of complete segmentation. On the other hand, their results are favorable to integration for more countries than has been the case in past studies on pre-1988 data sets, suggesting that the degree of integration has increased over time.

They then test an equation in which individual returns are determined by the world market beta plus the extra local portfolio beta in:eracted with the IFC investability index (which runs on a scale from 0 to 1 ). This seems like a test well-specified to distinguish the effects of segmentation from the inherent correlation of countries' economic disturbances. Yet the results are poor. Only when they look for an effect of the investability index on the level of price/eamings ratios, as opposed to the rate of return, do they find statistically 
significant effects: The higher is a country's degree of investability, the greater is the effective demand for its stocks and the higher their prices.

Claessens and Rhee suspect that the source of their difficulty in finding meaningful effects on rates of return is that ex post price changes are a very noisy indicator of ex ante expectations. Specifically, if a country starts off with some degree of segmentation, and then liberalizes during the sample period, its equity prices should rise at the same time. Investors in this country will have experienced capital gains during the sample period, as compared to another country that retains a high level of capital controls throughout. The first country shows a higher retum during the sample, even though the ex ante required rate of retum should in theory be higher in the second country. The lesson is that small-sample statistical tests that are implicitly based on an assumption of stationary structure are likely to go awry if used to study a period of structural change. This is an example of a failure of the rational expectations methodology, as distinct from the hypothesis of rational expectations or efficient markets per se, that plagues much empirical work throughout the finance field.

\section{The Location and Volume of Trading}

Usually in the study of equity markets, we abstract from issues regarding the volume of trading and the location of the trading. It is interesting to reflect, however, that the volume of the day's equity transactions in London, New York or Tokyo is the economic statistic that the audience of the CNN network and other information outlets apparently finds the second-most important of any. (Most-reported is the day's change in the stock market 
price index.)

What determines whether a given trade takes piace in one financial center or another? The location of the financial industry is not deeply rooted in fundamentals of comparative advantage. In Chapter 7, Campbell and Froot study the role of taxes on securities transactions. They examine two kinds of taxes: one in effect in Sweden, which is essentially a tax on domestic brokerage services, and another in effect in the United Kingdom, which is a tax on the legal transfer of ownership of UK equities. They find that both kinds of taxes lead to significant responses in the form of a fall in domestic trading. The response can involve either a shift of the same transactions offshore [though this is not an option in the UK case], a substitution into other similar (but untaxed) assets, or a decline in trading altogether.

Such research naturally has important implications for the securities industry itself, and potentially for public policy as well. The motivation of countries with securities transactions taxes is usually simply to raise revenue. The Swedish tax might be considered successful if its goal were to reduce the "excessive income" of securities traders. The UK tax might be considered successful if its goal were to reduce the volume of trading in particular UK assets, e.g., under the theory that "excessive trading" leads to "excessive volatility." Campbell and Froot conclude, however, that proposals to tax securities transactions as a source of tax revenue are less likely to be successful, unless perhaps the taxes can be imposed worldwide so as to prevent traders from shifting offshore.

The transactions tax experiment shows that relatively large shifts in the location of trading can result from relatively small changes in the cost of trading. [Similar implications 
presumably follow from other elements of trader costs, such as rents, telecommunications costs, and salaries of lawyers and translators.] The conclusion does not rule out the possibility, however, that the location and volume of trading are irrelevant to the determination of securities prices, beyond the epsilon-width band of arbitrage created by such costs. If location and trading volume are to have broader implications for securities prices, it is likely that imperfect information will have to play a role. It is considered below.

Timing around the globe, for example the closing of New York markets at 4:00 p.m. (EST) and the opening of Tokyo markets approximately three or four hours later (9:30 a.m. Japan time), offers a natural experiment to help answer a number of questions. Several researchers have noted the strengthened links between foreign markets and the U.S. market, particularly in the October 1987 crash and subsequently. ${ }^{20}$ In Chapter 8 of this volume, Ito and Lin focus on the interrelation of price movements, volatility clusters, and trading volumes, between the New York and Tokyo markets. They consider trading volume a possible proxy for heterogeneous beliefs, since investors would not trade if all were identical. This study makes a contribution to the literature on correlation across markets, by testing under what circumstances the correlation is higher than others. It also makes a contribution to the literature on trading volumes, by testing the effects from one market to the next.

Ito and Lin consider two competing hypotheses regarding correlation across markets. The first is that markets are imperfectly liquid, so that when a "liquidity trader" wishes to 
sell a stock in a hurry, he or she is obliged to give up a bit of return, which goes to the other class of traders ["informed traders"] as compensation. A testable implication of this hypothesis is attributed to Campbell, Grossman and Wang (1993): that a temporary upsurge in trading volume should cause a temporary decrease in returns, followed by a rebound in the subsequent period (i.e., negative autocorrelation). Ito and Lin, however, after looking in vain for evidence that trading volume in New York has a negative effect on the correlation between the New York and Tokyo markets, do not favor this hypothesis.

The competing hypothesis is that Japanese traders correctly infer from New York price movements information that is relevant to the pricing of their own stocks. Ito and Lin find that the correlation across the markets goes up when the volatility in New York goes up, which they think may be evidence in favor of this second hypothesis. It is surprising, however, that the authors find no evidence that volatility in Tokyo is associated with volatility in New York, as they have found in earlier work on the foreign exchange market. ${ }^{21}$ There is room for more research on the interaction of these variables. The use of direct data on the dispersion of beliefs among traders, as measured by the standard deviation of survey responses, might help.

\section{Country Funds and Investor Sentiment}

Most economists and finance specialists have long found unattractive the hypothesis that an important fraction of investors do not make full use of available information. After a 
decade of research into observed "anomalies" and some hard-to-explain upswings and crashes, however, there has recently been more serious consideration of the possible role of such factors as fads, bubbles, "noise traders," "feedback traders," etc..

Hardouvelis, La Porta, and Wizman make a fascinating contribution to the volume in their study of country funds in Chapter 9. These funds are well worth studying in their own right, as the leading wedge into some countries' emerging markets. By December 1992, U.S. investors could buy into twenty-six countries through one or more country funds traded on the NYSE and AMEX. The funds also offer a remarkable opportunity for one of the clearest tests to date of the Efficient Markets Hypothesis vs. the hypothesis that noise traders are important.

It is always difficult to test whether the market price of a stock is equal to its fundamental value, because of the uncertainty regarding what is the correct model of the fundamental value. There is little doubt, however, that the market price of a fixed portfolio of equities ought to be equal to the net asset value of the portfolio, that is, the aggregate of the market prices of the individual stocks. Closed-end country funds are just such fixed portfolios, and yet their prices when traded in New York are observed to differ substantially from their net asset values expressed in dollars.

Previous authors have observed the discrepancy between country funds and their respective net asset values. ${ }^{2}$ Hardouvelis, La Porta, and Wizman study how it moves through time. To summarize briefly the outcome of a systematic and thorough analysis, the New York prices of country funds are observed in the short nu to behave far more like the New York prices of other U.S. securities than to behave like the aggregated net asset value 
of the individual foreign securities that constitute the portfolio. Specifically, when there is a fluctuation in the exchange rate between the dollar and the currency of the local country in question, the country fund price tends in the short run to follow the dollar, not the local currency. When there is a fluctuation in the price of the world stock market, or small U.S. stocks, again the country fund price tends in the short run to follow the world portfolio or the U.S. stocks, not its respective local national stock market. Only slowly over time does the price converge to the net asset value as it should right away. (The weekly autoregressive coefficient is estimated at .89 , for a half-life of five weeks.) It is difficult to reconcile this behavior with the hypothesis of an efficient and frictionless world capital market.

Hardouvelis, La Porta, and Wizman interpret the data in terms of a model that allows for the presence of irrational investors, or noise traders. Collectively, these investors swing between being under- and over-optimistic about investment opportunities in particular foreign countries. In this context, the discount or premium on a country fund becomes a measure of the spontaneous pessimism or optimism with which U.S. investors view the country in question, relative to the investors within that same country.

Moreover, the common component of country fund discounts or premia across all New York-traded funds becomes an aggregate measure of general U.S. sentiment for all foreign countries, relative to local sentiment. A widespread interpretation of the specific timing of the 1982 international debt crisis is that domestic investors in such heavily-indebted regions as Latin America became concerned about future prospects of their countries, and moved large amounts of money out, at a time when northern investors were still enthusiastically lending. As one observes the renewed surge of capital into less developed 
countries during the period 1990-93, therefore, one should consider whether it is based on a degree of enthusiasm among northern investors that is not shared by the locals, who may be better-informed. Hardouvelis, La Porta, and Wizman observe a shift from discount to premium in 1990 in the prices of many country funds, which they attribute to contagious enthusiasm beginning with the fall of the Berlin Wall. It is interesting to note that discounts have particularly diminished or disappeared in Latin America and Central Europe since 1990. [In East Asia, on the other hand, premiums have fallen since 1990, suggesting that their stock market booms may have been led by domestic investors, rather than by foreigners.] One possible interpretation is that discounts and premiums are diminishing everywhere as restrictions are removed and the markets become more efficient. Another, more troublesome, interpretation is that U.S. investors may in 1990 have entered a temporary wave of enthusiasm for countries in Latin America and Central Europe.

In any case, the broader lesson to be drawn from the country fund study by Hardouvelis, La Porta, and Wizman, is the same as that to be drawn from the other contributions to this conference. International equity markets offer a wealth of new data, unique questions, and useful answers. Empirical studies should not merely treat foreign equities as one more asset to be added to the menu of investments considered by insular U.S. residents. They should, rather, take due account of the diversity of assets offered by countries around the world, the diversity of locales in which the universe of investors live, and the diversity of institutional peculiarities that characterize the markets in which assets and investors are brought together. 


\section{$\underline{\text { References }}$}

Adler, Michael and Bernard Dumas. 1983. International portfolio choice and corporation finance: A survey. Journal of Finance 38: 925-84.

Bollerslev, T., R.Engle and J. Wooldridge. 1988. A Capital Asset Pricing Model with Timevarying Covariances. Journal of Political Economy 96: 116-131.

Bosner-Neal, Catherine, Greggory Brauer, Robert Neal, and Simon Wheatley. 1990. International investment restrictions and closed-end country fund prices, Joumal of Finance 45: 523-547.

Brainard, William, and James Tobin. 1992. On the internationalization of portfolios, Oxford Economic Papers 44: 533-565.

Branson, William and Dale Henderson. 1985. The specification and influence of asset markets. In Ronald Jones and Peter Kenen, eds., Handbook of International Economics, vol. 2. Amsterdam: North-Holland.

Campbell, John and Kenneth Froot. Securities Transaction Taxes: Lessons from International Experience (this volume).

Campbell, J.,S. Grossman and J. Wang. 1993. Trading volume and serial correlation of stock returns, forthcoming, Quarterly Journal of Economics.

Claessens, Stijn, and Sudarshan Gooptu. 1993. World Bank Symposium on Portfolio Invesiment in Developing Countries, September 9-10.

Claessens, Stijn and Moon-Whoan Rhee. The Opening Up to Equity Investment by Developing Countries (this volume).

Diwan, Ishac, Lemma Senbet, and Vihang Errunza. 1993. The pricing of country funds and their role in capital mobilization for emerging economies, PRE Working Paper No. 1058, The World Bank.

Dombusch, Rudiger. 1983. Exchange risk and the macroeconomics of exchange rate determination. In R. Hawkins, R. Levich, and C. Wihlborg, eds., The Internationalization of Financial Markets and National Economic Policy. Greenwhich, Conn.: JAI Press.

Dumas, Bernard. 1993. Partial-equilibrium vs. general-equilibrium models of international capital market equilibrium. Weiss Center for International Financial Research 93-1. Forthcoming in Frederick van der Ploeg, ed., Handbook of International Macroeconomics, Oxford: Basil Blackwell. 
Dumas, Bernard. A Test of International CAPM with Economically Meaningful Instrumenta] Variables (this volume).

Dumas, Bernard, and Bruno Solnik. 1992. The World Price of Exchange Rate Risk, Working Paper, HEC School of Management, France.

Engel, Charles, Jeffrey Frankel, Kenneth Froot and Anthony Rodrigues. 1993. The Constrained Asset Share Estimation (CASE) Method: Testing Mean-Variance Efficiency of the U.S. Stock Market. NBER Working Paper No. 4294 (April). Forthcoming, Lournal of Empirical Finance.

Engel, Charles. Tests of CAPM on an International Portfolio of Bonds and Stocks (this volume).

Engel, Charies, and Anthony Rodrigues. 1989. Tests of International CAPM with TimeVarying Covariances. Journal of Applied Econometrics 4: 119-138.

Engel, Charles, and Anthony Rodrigues. 1992. Tests of mean-variance efficiency of international equity markets, Oxford Economic Papers, forthcoming.

Engle, Robert, Takatoshi Ito and Weng-Ling Lin. 1990. Meteor showers or heat waves? Heteroscedasticity of intra-daily volatility in the foreign exchange market, Econometrica 58: 525-542.

Errunza, Vihang, and Etienne Losq. 1985. International asset pricing under mild segmentation: Theory and test, Journal of Finance 40: 105-124.

Eun, C. and S. Shim. 1989. International transmission of stock market movements, Journal of Financial and Quantitative Analysis 24, 241-256.

Ferson, Wayne, and Campbell Harvey. 1993. The risk and Predict-ability of International Equity Returns, University of Chicago Working Paper, 1991. Forthcoming, Review of Financial Studies.

Ferson, Wayne, and Campbell Harvey. 1994. Sources of Risk and Expected Returns in Global Equity Markets, Journal of Banking and Finance, forthcoming.

Ferson, Wayne, and Campbell Harvey. An Exploratory Investigation of the Fundamental Determinants of National Equity Market Returns (this volume).

Frankel, Jeffrey. 1982. In search of the exchange risk premium: A six-currency test assuming mean-variance optimization. Journal of International Money and Finance 1 (December): 255-74. 
Frankel, Jeffrey. 1983. Estimation of Portfolio-Balance Functions that are Mean-Variance Optimizing: The Mark and the Dollar, European Economic Review 23, no.3 (December), 315-327.

Frankel, Jeffrey. 1985. Portfolio Shares as 'Beta-Breakers': A Test of CAPM, Joumal of Portfolio Management 11, no. 4 (Summer), 18-23.

Frankel, Jeffrey and Charles Engel. 1984. Do investors optimize over the mean and variance of real retums? A six currency test. Joumal of Intemational Economics 17: 309-23.

French, Kenneth, and James Poterba. 1991. Investor diversification and intemational equity markets, American Economic Review 81 (May): 222-226.

Froot, Kenneth. 1993. Currency hedging over long horizons: Empirical evidence, Paper presented at NBER Summer Institute, International Finance and Money, July 23; revised version of NBER Working Paper No. 4355.

Giovannini, Alberto, and Philippe Jorion. 1989. The time variation of risk and return in the foreign exchange and stock markets, Journal of Finance 44, no. 2, June: 307-325.

Golub, Stephen. 1991. International diversification of social and private risk: The U.S. and Japan. Swarthmore College, November.

Grauer, F. L. A., R. H. Litzenberger and R. E. Stehle. 1976. Sharing rules and equilibrium in an international capital market under uncertainty. Joumal of Financial Economics 3, 3: 233-56.

Hardouvelis, Gikas, Rafael La Porta, and Thierry Wizman. What Moves the Discount on Country Equity Funds? (this volume).

Harvey, Campbell. 1989. Time-varying conditional covariances in tests of asset pricing models, Joumal of Financial Economics 24, 289-317.

Harvey, Campbell. 1991. The world price of covariance risk, The Journal of Finance 41: $111-157$.

Harvey, Campbell. 1993. Portfolio Enhancement Using Emerging Markets and Conditioning Information. World Bank Symposium on Portfolio Investment in Developing Countries, organized by Stijn Claessens and Sudarshan Gooptu, September 9-10.

Ito, Takatoshi and Weng-Ling Lin. Price Volatility and Volume Spillovers Between the Tokyo and New York Stock Markets (this volume).

King, Mervyn and Sushil Wadwhani. 1990. Transmission of volatil-ity between stock 
markets. Review of Financial Studies 3: 5-33.

Kouri, Pentti and Jorge de Macedo. 1978. Exchange rates and the international adjustment process: Brookings Papers on Economic Activity 1: 111-50.

Obstfeld, Maurice. 1993. International capital mobility in the 1990s (August). Forthcoming, 1994, in Peter Kenen, ed., Understanding Interdependence: The Macroeconomics of the Open Economy Princeton: Princeton University Press.

Perold, Andre, and Evan Schulman. 1988. The free lunch in currency hedging: Implications for investment policy and performance standards, Financial Analysts Journal, May/June: 45so.

Roll, Richard. 1977. A Critique of the Asset Pricing Theory's Tests; Part I On Past and Potential Testability of the Theory, Journal of Financial Economics 4: 129-176.

Solnik, Bruno. 1974. An equilibrium model of the international capital market. Joumal of Economic Theory 8, 4: S00-24.

Stock, James and Mark Watson. 1992. A Procedure for Predicting Recessions with Leading Indicators: Econometric Issues and Recent Experience, NBER Working Paper No. 4014.

Stulz, Rene. 1981a. A model of international asset pricing, Journal of Financial Economics 9, 383-406.

Stulz, Rene. $1981 \mathrm{~b}$. On the effects of barriers to international investment, Journal of Finance $36,923-934$.

Stulz, Rene. 1984. Pricing capital assets in an international setting: An introduction, Journal of International Business Studies 15, S5-74.

Summers, Lawrence. 1985. On Economics and Finance. Journal of Finance 40, no.3, July: $633-35$

Tesar, Linda and Ingrid Werner. 1992. Home Bias and the Globalization of Securities Markets, NBER Working Paper No. 4218.

Tesar, Linda and Ingrid Werner. International Equity Transactions and U.S. Portfolio Choice (this volume).

Thomas, S.H., and M.R. Wickens. 1993. An International CAPM for Bones and Equities. Journal of International Money and Finance 12, no.2, August: 390-412.

von Furstenberg, George, and B.N. Jeon. 1989. International stock price movements: Links and Messages, Brookings Papers on Economic Activity 1: 125-167. 


\section{$\underline{\text { Notes }}$}

1. The cross-over appears to have occurred earlier, if one does not adjust the Japanese stockmarket for cross-holdings. Using either basis of comparison, the U.S. market regained the lead soon thereafter.

2. Claessens and Rhee, this volume. A third of the flow over the four-year period took place via country funds.

3. A classic reference that follows this approach is Grauer, Litzenberger and Stehle (1976).

4. Solnik (1977) first modeled investors in each country as caring only about returns expressed in their own country's terms, because they consume no foreign goods and domestic goods prices are non-stochastic. The more general framework in which investors have a home-country bias based on consumption patterns (the "preferred local habitat" model) was developed by Kouri and de Macedo (1978), Dombusch (1983) and Frankel (1982) in the economics literature, and Stuiz (1981a) and Adler and Dumas (1983), a classic survey, in the finance literature.

5. They cite Stulz (1984) for the conditions under which a single-beta CAPM based on a world market portfolio holds.

6. Harvey (1989) tests the proposition.

7. Many researchers follow the strategy of, first, developing a complete intertemporal optimization theory, and then -- when it comes time to test, and the empirical counterparts of the theoretical "state variables" are nowhere to be found - adopting convenient observable variables as proxies.

8. Some of these attractions were also claimed by the tests in Frankel $(1982,1983,1985)$ and Frankel and Engel (1983). But the technique has in the past included only a limited set of assets -- thus being subject to the Roll critique. Furthermore, the four papers cited also required that the variances and covariances be constant over time.

9. The GARCH version of the CASE method has also been tested by Engel and Rodrigues (1989), and Engel, Frankel, Froot, and Rodrigues (1991). The application of the technique by Giovannini and Jorion (1989) added the U.S. stock market to the set of international bonds considered in the earlier papers, and conditioned variances on the level of interest rates. Like the earlier papers, it rejected the CAPM hypothesis. Engel and Rodrigues (1993) included a range of countries' stock markets, and conditioned variances on a set of economic variables like some of the instrumental variables used in the Dumas and FersonHarvey contributions to the present volume. 
10. A great many researchers have found an ability to predict expected return differentials using ad hoc predictors. Within the constraints of CAPM, however, previous tests such as Frankel (1982) and Giovannini and Jorion (1989) have been unable to reject the hypothesis that expected returns are equalized across countries. Engel suggests that this may be due to the failure to consider a full set of bonds and equities, or to allow the variances to vary.

11. Thomas and Wickens (1993) apply the CASE method to a portfolio of four countries. bonds and equities. They obtain a rejection of CAPM, like the earlier studies citcd in footnotes 6 and 7 and other applications of the technique. Their study has all the advantages of Engel's -- a reasonably complete international set of assets, time-varying variances. conditional expected returns that can vary freely, an explicit test of CAPM against an alternative hypothesis -- except that it is missing investor heterogeneity.

12. Once again, the portfolio-balance theory has traditionally been of greater interest to economists than to finance specialists. Branson and Henderson (1985) is one survey of the portfolio balance model, with emphasis on the finance perspective. A recent example is Brainard and Tobin (1992).

13. Jorion, this volume.

14. Recent surveys by Dumas (1993) and Obstfeld (1993) each devote sections to this observed bias and its possible explanations.

15. One of many possible examples is Frankel (1983), equations (1) and (3).

16. Perold and Schulman (1988). This prescription, and many of the other conclusions that follow from the one-period mean-variance model, change if investors are obliged to take into consideration longer horizons. Sce Froot (1993).

17. Enel tests the version of the international CAPM that does not allow any home-country bias in equities whatsoever, which is a particularly extreme version of the model, the Solnik form, in which investors ase assumed to consider the home currency completely safe, because they are assumed to consume no foreign goods whatsoever. There is room for generalization of the test here to allow for some uncertainty in the investors home-currency consumer price index, but a different result seems unlikely.

18. Stulz (1981b) and Errunza and Losq (1985) are examples of the theory and testing, respectively, of segmented equity markets.

19. Many of the authors working on this subject have recently been brought together by Claessens and Gooptu (1993). 
20. E.g., Eun and Shim (1989), King and Wadwhani (1990) and von Furstenberg and Jeon (1989). Shiller, Konya and Tsutsui (1991) conclude from a systematic study of questionnaires that traders in the crash were responding in an immediate sense to news about U.S. price movements per se, not to news about economic fundamentals.

21. Engle, Ito and Lin (1990) use the term "meteor showers," to describe volatility clusters that persist, not only from one trading day to the next, but from one time zone to the next.

22. For example, Bosner-Neal, Braver, Neal and Wheatley (1990) and Diwan, Senbet and Errunza (1993). 